\title{
MINUMAN DAUN YACON SEBAGAI PRODUK UNGGULAN MASYARAKAT SENDURO
}

\author{
Oleh: \\ 1)Leny Yuanita, 2)Prima Retno Wikandari, 3)Rinie Pratiwi Puspitasari, \\ 4)Wahyu Budi Sabtiawan, 5)Dhita Ayu Permata Sari \\ 1),2) Jurusan Kimia, FMIPA Universitas Negeri Surabaya \\ 3) Jurusan Biologi, FMIPA Universitas Negeri Surabaya \\ 4),5) Jurusan Kimia, FMIPA Universitas Negeri Surabaya \\ 1)email: lennyyuanita@unesa.ac.id
}

\begin{abstract}
Abstrak
Target dari kegiatan pengabdian ini adalah pemberdayaan masyarakat Desa Argosari, Senduro untuk menghasilkan minuman daun yacon yang siap jual. Kegiatan ini melibatkan dosen, mahasiswa, kelompok tani, dan warga desa. Ada tiga tahap dalam kegiatan ini, meliputi persiapan, pelaksanaan, dan evaluasi. Pelatihan yang dilakukan meliputi pembuatan minuman daun yacon dan pengemasan produk. Pembuatan minuman dilakukan dengan tahap pemilihan, penghancuran, dan pengeringan. Setelah itu, dilakukan pengemasan menggunakan alumunium foil. Kegiatan pengabdian dilakukan selama 8 bulan dimulai pada bulan Februari sampai dengan September 2017. Produk yang dihasilkan selama proses kegiatan berupa minuman teh daun yacon siap jual. Mahasiswa telah mampu bersosialisasi dengan masyarakat Desa Argosari melalui program pengolahan yacon dan pengurusan ijin P-IRT. Nomor P-IRT yang diperoleh untuk minuman daun yacon adalah P-IRT No. 2133508030333-22.
\end{abstract}

Kata Kunci: minuman daun yacon, pengemasan, Senduro

\begin{abstract}
The target of the community service was the empowerment of the community of Argosari Village, Senduro to produce a ready-to-sell yacon leaf drink. This activity involved lecturers, students, farmer groups, and villagers. There were three stages in this activity, including preparation, implementation, and evaluation. The training included making yacon leaf drink and packaging of product. The community service were conducted for 8 months starting from February to September 2017. The product was a ready-to-sell yacon leaf drink with certificate number of P-IRT No. 2133508030333-22. In addition, the students have been able to socialize with Argosari Village community through yacon processing program and $P$-IRT permit arrangement.
\end{abstract}

Keywords: yacon leaf drink, packaging, Senduro

\section{PENDAHULUAN}

Yacon merupakan tanaman yang adaptif terhadap ketinggian tempat, tetapi tanaman ini lazimnya tumbuh di daerah (pegunungan Andes) yang memiliki ketinggian antara $500-2750 \mathrm{~m}$ dpl (Fernandez, 2007). Yacon [Smallanthus sonchifolia (Poepp.et Endl.) H.Robinson] merupakan tanaman berumbi yang berasal dari pegunungan Andes (Fernandezet et al., 2007). Tanaman ini memiliki beberapa manfaat, antara lain pemanis alami, aktivitas hipoglikemik atau anti-diabetes (Hermann et al., 1998; Aybar et al., 2001), anti-jamur (Pinto etal., 2001; Inoue et al. 1995), dan pencegah kanker (Goncales et al., 2003). Hal ini dikarenakan tanaman yacon memiliki beberapa kandungan senyawa kimia, diantaranya adalah gula sederhana, fruktooligosakarida, dan asam klorogenat. Antioksidan asam klorogenat didapatkanpada daun dan umbi yacon, dengan persentase tertinggi pada umbi (Yan et al., 1999). Daun yacon berperan dalam penurunan glukosa, kolesterol darah, antibakteri, dan fungisida (Lachman et al., 2003). Dengan demikian, yacon merupakan tanaman yang bermanfaat dan mampu memberikan dampak ekonomi terhadap pembudidaya dan pengelolah tanaman tersebut.

Indonesia merupakan negara dengan yang memiliki daerah-daerah dengan dataran tinggi. Desa Argosari terletak di Kecamatan Senduro Kabupaten Lumajang. Desa ini memiliki luas 228,67 $\mathrm{km}^{2}$ dengan ketinggian wilayah di Desa Argosari berkisar antara 200 hingga 2900 meter di atas permukaan laut. Pendudukan Desa Argosari sebagian besar hidup di sektor pertanian sebagai petani dan 
buruh tani sayuran. Beberapa penduduk berprofesi sebagai Pegawai Negeri Sipil dan sebagian lainnya sebagai pedagang. Tingkat kesejahteraan penduduk secara umum masih tergolong menengah ke bawah.

Dalam RPJMD Kabupaten Lumayang Tahun 2015-2019 dijelaskan bahwa visi dan misi kabupaten tersebut adalah "Terwujudnya Masyarakat Lumajang yang Sejahtera dan Bermartabat" dengan salah satu misinya adalah "Meningkatkan Perekonomian Daerah dan Masyarakat Berbasis Pertanian". Selain visi dan misi, RPJMD tersebut juga mengungkapkan mengenai masalah yang dihadapi oleh Kabupaten Lumajang, antara lain belum optimalnya pertumbuhan sektor pertanian danpotensi hutan rakyat masih perlu dioptimalkan (Pemkab Lumajang, 2015). Dengan demikian, perlu adanya optimalisasi lahan pertanian di Kabupaten Lumajang khususnya Desa Argosari.

Pada tahun 2016, tanaman yacon telah dibudidayakan di lahan tersebut melalui program KKN-PPM bersama dosen dan mahasiswa Unesa, serta petani di Desa Argosari. Kegiatan yang berlangsung dalam kurun waktu 3 bulan tersebut menitikberatkan pada upaya pembudidayaan tanaman yacon untuk menghasilkan tanaman yacon yang berkualitas. Mahasiswa (selama dua hari dalam seminggu) mengunjungi Desa Argosari untuk mengecek pertumbuhan tanaman tersebut. Selama proses pembudidayaan, petani dan tim pelaksana KKN-PPM tidak menemukan kendala yang berarti karena tanaman yacon ini merupakan tanaman yang mudah tumbuh dan tidak memerlukan perawatan ekstra.

Mempertimbangkan kondisi pembudidayaan yang telah berjalan di Desa Argosari dan manfaat tanaman yacon tersebut serta nilai ekonomis tanaman tersebut, maka maka tujuan kegiatan ini adalah membuat produk olahan yacon sebagai upaya peningkatan kesejahteraan masyarakat Desa Argosari, Senduro dan memberi keterampilan mahasiswa untuk bersosialisasi dan memecahkan masalah di masyarakat.

\section{METODE}

Kegiatan ini meliputi tiga tahap yaitu persiapan, pelaksanaan, dan evaluasi. Tahap persiapan terdiri atas kegiatan observasi lapangan, perijinan, pembekalan mahasiswa, koordinasi dengan mitra, dan pemilihan lokasi untuk pelatihan. Tahap pelaksanaan yaitu tahap dimana tim melatihkan pembuatan dan pengemasan minuman daun yacon kepada kelompok tani dan masyarakat. Tahap berikutnya merupakan tahap evaluasi, dimana Dinkes Lumajang akan melakukan observasi dan evaluasi ke lapangan terhadap produk yang telah dihasilkan, apakah layak mendapatkan sertifikat P-IRT atau tidak.

\section{HASIL DAN PEMBAHASAN}

Penjelasan pada bagian ini dibagi menjadi tiga komponen besar, yaitu persiapan, pelaksanaan, dan evaluasi. Ketiga komponen tersebut akan dijelaskan lebih lanjut sebagai berikut.

\section{Persiapan}

Tim

Pelaksanan

KKN-PPM

berkoordinasi dengan Kepala Desa dan petani lokal yang telah menanam yacon. Petani lokal dan Kepala Desa mempersiapkan tempat produksi. Setelah tempat produksi telah siap, mahasiswa diberikan pelatihan oleh dosen pembimbing selama tiga hari dengan rincian kegiatan dua hari kegiatan pelatihan berupa workshop pelatihan membuat produk minuman teh yacon di Kampus Unesa Ketintang. Pelatihan hari ke 1 membahas tentang teknis pelaksanaan kegiatan, tujuan program pengabdian, manfaat tanaman yacon yang telah ditanam oleh petani, dan pembagian kelompok mahasiswa. Pelatihan hari ke 2 membahas tentang prosedur pengolahan yacon menjadi produk yang layak jual. Mahasiswa berdiskusi bersama kelompok merinci alat dan bahan yang akan mereka butuhkan selama kegiatan pengabdian. Dalam pelatihan ini mahasiswa juga mendesain kemasan yang menarik dan siap dipakai oleh petani lokal di Desa Argosari, Lumajang. Desain tersebut dikonsultasikan ke DPL, kemudian dicetak untuk dibawa ke lokasi program KKN-PPM. Pelatihan hari ketiga digunakan untuk melatihkan mahasiswa membuat produk olahan yacon, yaitu minuman daun yacon. Selain itu, mahasiswa juga diberi wawasan tentang pengurusan ijin P-IRT dan diminta mempersiapkan kebutuhan untuk pengurusan perijinan di Dinas Kesehatan setempat.

\section{Pelaksanaan}

Program KKN-PPM dibagi menjadi dua tahap, yaitu tahap pembuatan minuman daun yacon dan pengemasan. Pelaksanaan Program KKN-PPM diawali dengan pembukaan kegiatan KKN-PPM di Desa Argosari, Lumajang, pada tanggal 3 Maret 2017 yang dihadiri oleh Kepala Desa Argosari 
dan petani local, seperti yang terlihat pada Gambar 1.

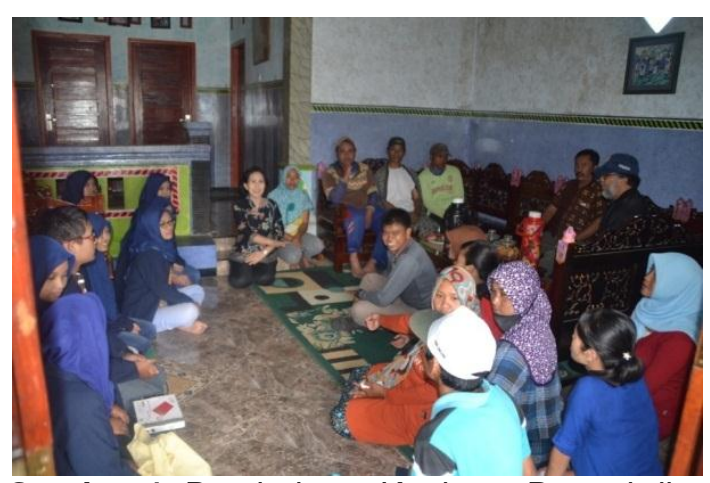

Gambar 1. Pembukaan Kegiatan Pengabdian

Selanjutnya, masih pada tanggal yang sama, kegiatan dilanjutkan dengan persiapan pengolahan minuman daun yacon dan sosialisasi pemanfaatan daun yacon, yang divisualisasikan di Gambar 2.

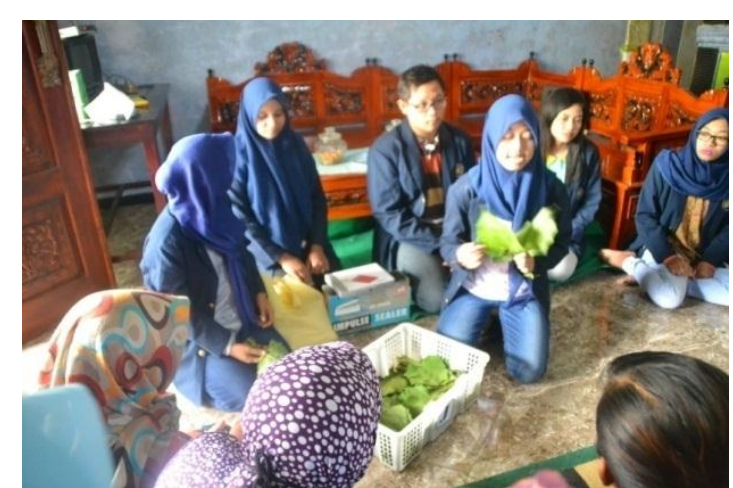

Gambar 2. Sosialisasi dan Pemaparan Cara Pembuatan Minuman Daun Yacon

Teknik pembuatan minuman daun yacon meliputi proses pengeringan, pendinginan, penggilingan, dan pengemasan. Minuman yang dibuat menyerupai teh tubruk. Proses pengeringan menggunakan oven pengering seperti yang terlihat pada Gambar 3.

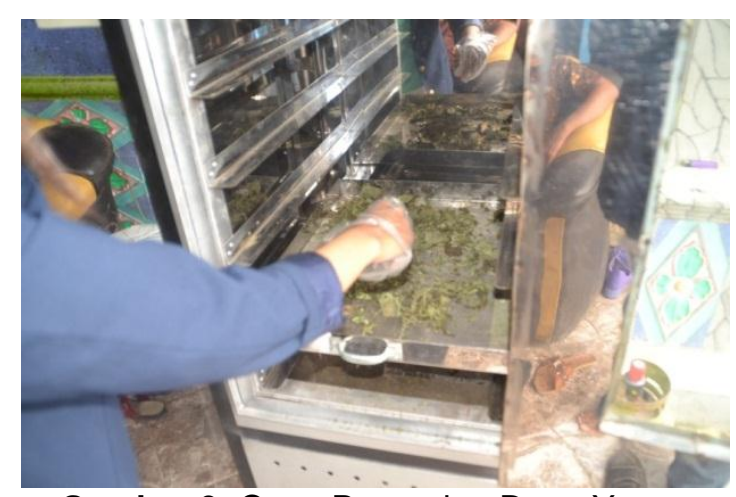

Gambar 3. Oven Pengering Daun Yacon
Setelah daun kering, daun tersebut didinginkan kemudian digiling menggunakan chopper sederhana seperti pada Gambar 4.

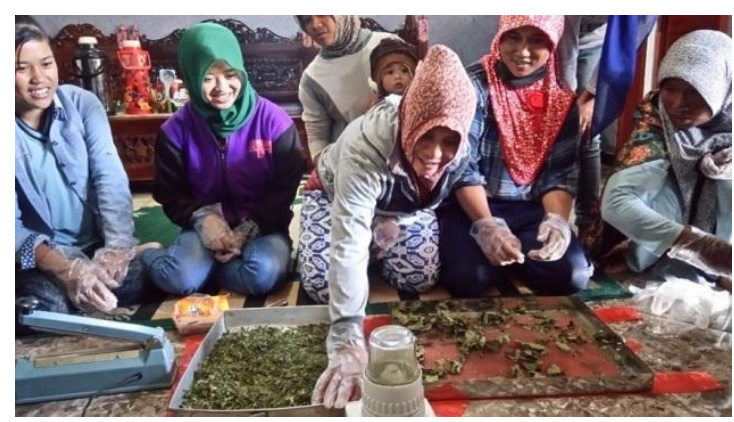

Gambar 4. Penggilingan Daun Yacon Kering

Tahap selanjutnya, setelah daun telah siap, yaitu pengemasan daun yacon. Pengemasan minuman daun yacon dilakukan dengan cara memasukkan daun yang telah siap ke dalam kantong-kantong berbahan aluminium foil sehingga dihasilkan satu kantong untuk tiap porsi minuman daun yacon. Beberapa kantong tersebut dikemas ke dalam satu kotak kemasan minuman yacon yang telah memiliki logo minuman daun yacon. Pada kegiatan tahap $1 \mathrm{ini}$, petani lokal membentuk kelompok petani yacon yang nantinya mengelola pembuatan produk dan penjualan produk bernama Putri Tengger. Berdasarkan hal tersebut, mahasiswa mendesain ulang kemasan yang telah dibuat sehingga nama kelompok tani 'Putri Tengger' masuk dalam kemasan minuman daun yacon, seperti yang terlihat pada Gambar 5
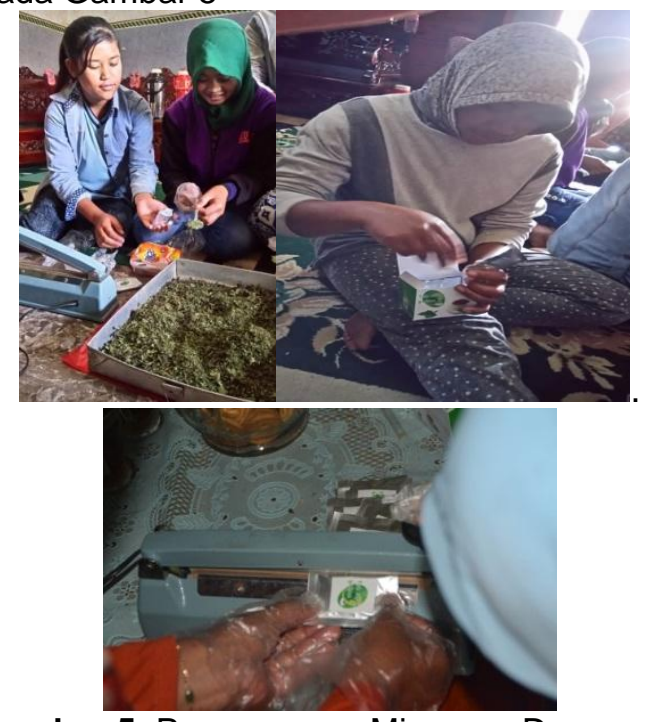

Gambar 5. Pengemasan Minuman Daun Yacon ke dalam Kantong Aluminium Foil dan Kemasan Kardus 


\section{Evaluasi}

Pada tahap ini lebih menitik beratkan pada judgment apakah kegiatan pengabdian berhasil atau tidak. Parameter keberhasilan kegiatan adalah didapatkannya ijin P-IRT kepada Dinas Kesehatan Kabupaten Lumajang. Pengajuan ijin P-IRT dimulai dengan survey awal dan pengajuan form ke Dinas Kesehatan Kabupaten Lumajang pada 17 Juni 2017. Selanjutnya, pada 25 Juli 2017 Dinas Kesehatan Kabupaten Lumajang melakukan kunjungan ke Kelompok tani Putri Tengger (IRT Putri Tengger) seperti yang terlihat pada Gambar 6. Berdasarkan survey tersebut, mahasiswa mendapat masukan untuk merevisi desain kemasan dan brosur yang dibuat. Saran lain yang didapat adalah penggantian nama 'teh yacon' menjadi 'minuman daun yacon'. Selanjutnya, mahasiswa membantu IRT Puteri Tengger merevisi desain kemasan dan brosur sesuai saran yang diberikan. Dinas kesehatan memberikan masukan untuk box minuman daun teh yacon seperti pada Gambar 7. Revisi tersebut meliputi nama produk, nama produsen, kode produksi, netto, dan expired date. Setelah itu, dilakukan revisi yang terlihat seperti pada Gambar 8. Setelah revisi, diperoleh hasil berupa nomor ijin P-IRT yaitu P-IRT No. 2133508030333-22 untuk Minuman Daun Yacon.

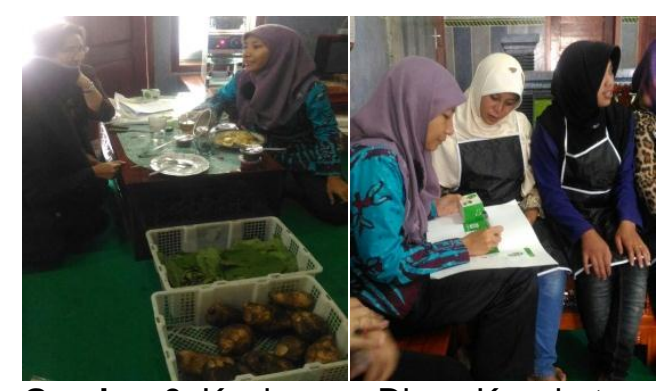

Gambar 6. Kunjungan Dinas Kesehatan Kabupaten Lumajang untuk Perijininan P-IRT produk olahan yacon

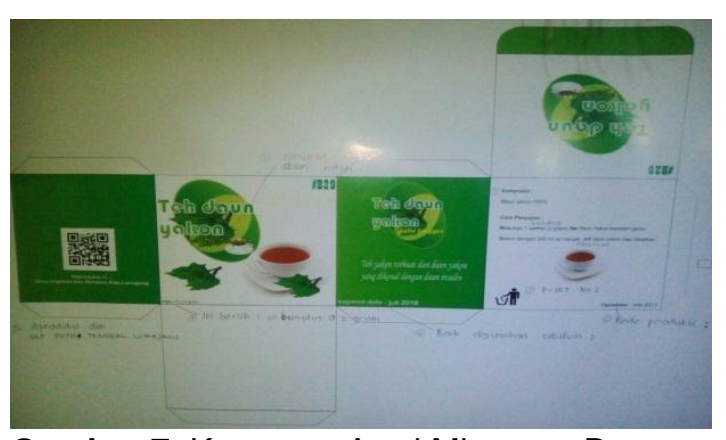

Gambar 7. Kemasan Awal Minuman Daun Yacon

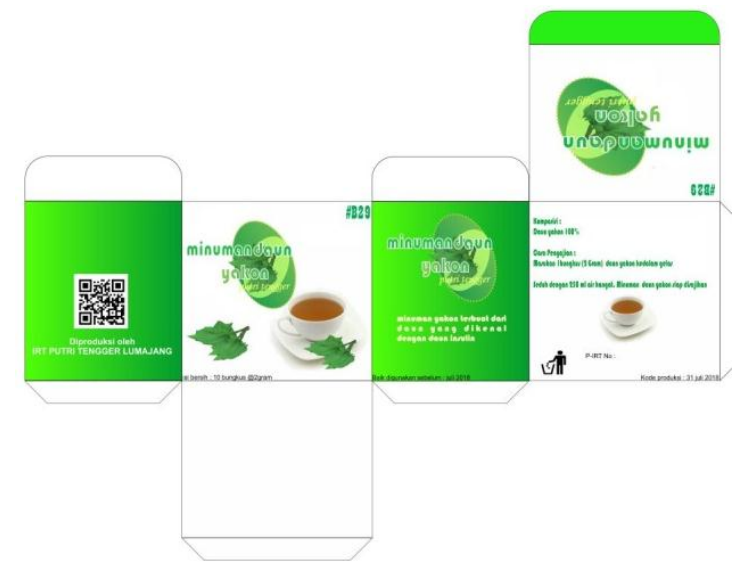

Gambar 8. Kemasan Revisi Minuman Daun Yacon

\section{SIMPULAN DAN SARAN \\ Simpulan}

1. Masyarakat di Desa Argosari dapat diberdayakan melalui pembuatan produk olahan yacon berupa minuman daun yacon.

2. Mahasiswa KKN telah mampu bersosialisasi dengan masyarakat Desa Argosari melalui program pembuatan produk olahan yacon.

3. Telah dihasilkan produk minuman daun yacon yang siap jual dengan P-IRT No. 2133508030333-22.

\section{Saran}

Saran untuk kegiatan KKN-PPM selanjutnya adalah standarisasi dan memasarkan produk olahan yacon ke jangkauan yang lebih luas dan profesional.

\section{DAFTAR PUSTAKA}

Aybar MJ., Riera ANS., Grau A., Sanchez SS. (2001). Hypoglicemic Effect of the Water of (yacon) Leaves in Normal and Diabetic Rats. J. Ethnopharmacol. 125132

Fernandez, C.E., Viehmannova I., Bechyne M., Lachman J., Milella L, Martelli G., 2007. The Cultivation and Phenological Growth Stages of Yacon [Smallanthus Sonchifolius (Poepp. Et Endl.) H. Robinson. Agricultura Tropica et Subtropica, 40(3) 
Goncales, E., JD. Felicio. MM. Pinto, MH. Rossi, C. Medina, MJB. Fernandes, elC. Simoni. 2003. Inhibition of Aflatoxin Production by Polymnia sonchifolia and its in Vitro Cytotoxicity. Arq. Inst. Biol., 70(2), 159-163

Hermann, M., I. Freire, C. Pazoa. 1998. Compositional Diversity of the Yacon Storage Root. CIP Program Report

Inoue A., Tamogami S., Kato H., Nakazato Y., Akiyama M., Akatsuka T., Hashidoko Y., 1995.Antifungal melampolides from leaf extracts of Smallanthus sonchifolius. Phytochemistry, 39(4), 845-848

Lachman J., Fernandez EC., Orsak M. 2003. Yacon [Smallanthus sonchifolius (Poepp. Et Endl.) H. Robinson] Chemical Composition and Use- A review. Plant Soil Environ.,49(6):283290.

Pinto, MM., Goncales, E., MH. Rossi, JD. Felicio., CS. Medina, MJB. Fernandes, IC. Simoni. 2001. Activity of the Aqueous Extract from Polymnia sonchifolia Leaves on Growth and Production of Aflatoxin B1 by Aspergillus flavus. Braz. J. Microbiol., $32,127-129$

Yan, XJ., Suzuki M., Obnishi-Kameyama M., Sada Y., Nakanikshi T., Nagata T. 1999. Extraction and Identification of Antioxidants in the Root of Yacon (Smallanthus sonchifolius). Journal of Agricultural and Food Chemistry,47(11), 4711-4713

Pemerintah Kabupaten Jombang. 2015. Diakses melalui www.lumajang.go.id pada tanggal 3 Maret 2015. 